\title{
Andries van Aarde - A sideways glance: His theological and hermeneutical contribution to the South African scene
}

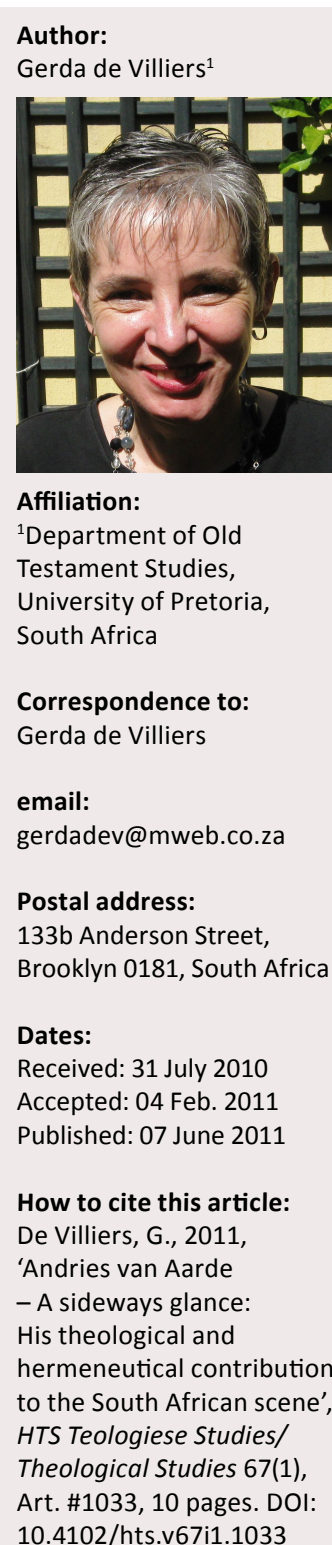

10.4102/hts.v67i1.1033

C 2011. The Authors. Licensee: OpenJournals Publishing. This work is licensed under the Creative Commons Attribution License.
This article pays tribute to Andries van Aarde's theological and hermeneutical contribution. His research unfolds in three phases: a narrative reading of the text, a social scientific investigation of the context and an 'ideal construct' of the historical Jesus. Despite the theoretical nature of these inquiries, Van Aarde indicates convincingly their practical value for the church and society on the whole.

\section{A step to the side: Into the text}

The way in which the Bible has been transmitted, received and interpreted has been and still is heavily debated. Into this scenario steps Andries van Aarde.

At the beginning of the 1980s, biblical interpretation was stuck in a blind alley of traditional approaches: historicism and positivism on the one hand and structural analysis on the other, both of which aimed to provide the exegete with an 'objective' grip on the text. Van Aarde has always valued the role of genre in biblical exegesis and hermeneutics, which means distinguishing between gospel, acts, epistle and apocalypse. However, he became increasingly frustrated with the inadequacy of this distinction and began hearing the voice of the narrator of the text. Who is telling the story? For whom is it intended?

Especially: what does it aim to achieve? Van Aarde reads the gospels as narratives in accordance with the principles of modern literary theory. According to the classical hermeneutical communication model, there is always a sender, a message and a recipient involved in the communication process. Van Aarde (1983:58-82) focuses especially on the narrative point of view, that is, the way in which the narrator presents the story and what outcome the narrator has in mind. No narrative is free from the ideology of the narrator. From this ideological framework, the narrator creates characters who assume the roles of protagonists or antagonists and who act in a constructed world of space and time.

According to Andries van Aarde (1983:76-80), the gospels are not historical reports about the life and death of Jesus, but are narratives, permeated with the intrinsic ideology (theology) of the narrator, who aims to draw readers into the story so that they can participate in the events.

The question is, however, whether these insights have practical relevance, for example for preaching, or whether they are just theories from ivory tower academia? According to Van Aarde (1984:123-146), engaging with the intention of a text certainly has practical value. After all, a sermon is a communicative event.

The first step in this process is when the preacher engages with the text and seeks to discover its intention. Van Aarde proposes a different set of questions to that of genre. The two main questions are whether the text is argumentative by nature, inviting the reader to follow the rhetorical line of thought, or whether is it a narrative text that lures the reader into the plot. Understanding the way in which a text communicates has implications for exegesis and communication. The process of communication is twofold: firstly between text and preacher and secondly between preacher and audience. Ideally, the whole process should entail a Horizontverschmelzung, a fusion of horizons of text, preacher and audience.

Van Aarde moves away from the traditional model of explicatio or applicatio: firstly explaining the text and then making it relevant for the contemporary context, in other words, illuminating how to move from text to sermon. The pitfalls in this regards include spiritualisation, allegorising or drawing direct parallels between the text and today's world, some of which are more successful than others. What the text communicates, why it does so and its implicit outcome, can be integrated into the structure of a sermon. 
Van Aarde specifically applies his narrative approach to the Gospel of Matthew. In an article (Van Aarde 1985) he argues that 'God with us' (Immanuel) is a key phrase in the Gospel of Matthew, which occurs strategically at die beginning (1:23), in the middle (18:19) and at the end (28:18). The ideology of the narrator of the Gospel of Matthew is strongly influenced by 'God with us'. This determines the way in which he reads and re-structures the Gospel of Mark and it also influences his understanding of Jesus (Van Aarde 1985:272-289).

In a subsequent book (Van Aarde 1994a) entitled God-with-us: The dominant perspective in Matthew's story, it becomes clear that the 'dominant perspective' refers to the narrator's point of view, which also reveals his theology. In other words, the narrator has certain ideas which he chooses to convey in a particular manner by means of literary techniques. 'Ideas' and 'techniques', concepts borrowed from literary criticism, imply much more than the usual distinction between 'form' and 'content'. They become powerful hermeneutical tools to aid textual exegesis and which help the reader to discover the intention of the text and even to become part of the story.

'God-with-us' is the dominant perspective of the narrator of the Gospel of Matthew. The heart of the message is that God is present in a limitless and unmediated way. The narrator uses two narrative lines to expound this idea; he tells a story within a story. The first narrative line is God's unmediated presence in the pre-Easter Jesus, who reaches out to the marginalised and outcasts of the society. Analogous to the Jesus story is the story of the post-Easter disciples, who continue to follow Jesus' example. They become manifestations of 'God-withus' to outsiders.

Van Aarde (1994:xiv) assumes that the Matthean gospel also reveals something of the social context of the intended readers. Most probably, they lived c.a. $70 \mathrm{AD}$, the time of formative Judaism and tension between the synagogue and the church. In the Matthean community, some people in leadership positions chose to conform to the ideology of the Pharisees in their behaviour and attitude, thereby deviating from the example of Jesus. The narrator employs narrative techniques to express his theological idea of 'Godwith-us'. He draws the reader into the primary sequence of the narrative, the commission of Jesus before Easter and exhorts them to become part of the secondary sequence, the commission of the disciples after Easter. The 'God-with-us' theme gives the narrator a basis of authority by which he addresses the readers and succeeds in drawing them into the story. In the new hermeneutics, this communication event is called Einverständniss or Eindringlichkeit.

During the 1980s to the 1990s, Andries van Aarde produced groundbreaking work with his literary approach to reading the gospels. In the first place, these works could be treated not as historical documents, but as skilful literary creations. Furthermore, he stripped them of dogma, which usually coloured exegetes' approach even before they read the texts themselves. All texts, including biblical texts, are literary inventions, thus, a world on paper. The aim of the narrator is to make this paper world real to the readers, inviting them to become characters in the story as it were.

Although Van Aarde would soon turn towards other approaches to the text, he did not take leave of literary theory altogether. In 2006, he wrote a series of two articles in which he first expounds genre and plot in the gospel material (2006a:657-677), followed by an analysis of the narrator's point of view in New Testament texts (2006b:11111143). In these two articles he combines historical criticism and narrative criticism. He also employs some of the most sophisticated, even abstract, narrative theories (e.g. Gérard Genette and Mieke Bal).

\section{Another sidestep: Into the context}

During the mid-1980s, Andries van Aarde became increasingly involved in research done by the Context Group, an international US based research project that focuses on the interpretation of texts within the parameters of social scientific models. Here, Van Aarde's appreciation of the narrative is supplemented with social scientific theories. 'Every text, including a narrative discourse', he writes (Van Aarde 1988a:235), 'reflects the social context from which it originates, although in truncated form, presented from a particular ideological perspective.' The text placed in its historical context. After all, a narrative originates within a particular context, for which its meaning is intended. Biblical exegesis and the consequent hermeneutical exercise therefore have to pay close attention also to the world and circumstances outside the text. Van Aarde (1988a:237) calls these forces, the mechanisms that generate texts, 'culture'. Thus, texts are not only determined by the ideology of the narrator, but also by the culture in which they were written. Consequently Van Aarde (1988a:237) states: 'In this connection, therefore, the term "culture" can be replaced by the term "social context"'.

Van Aarde then extends his appropriation of literary theory to incorporate the social context. Instead of a one-way direction from 'sender to message to recipient', a circular movement is indicated: from recipient, to sender, to message to recipient. The recipients and the world in which they function, bring texts into being, that is, the social context co-determine the production as well as the meaning of texts.

Thus, the narrative, as well as the social context, is important to convey the meaning of the text. Put differently, intratextual as well as extra-textual concerns are involved in the whole process of communication. These have far reaching implications for biblical exegesis and hermeneutics. However, how do modern day readers gain access to the social context, the extra textual world? How do they build a 'construction' of an unfamiliar world? The first and foremost clues to the extra textual world are provided by the text itself. But there may be other sources which serious exegetes will take into account even before they read the biblical text in question.

For example: the Gospel of Luke and consequent Acts of the Apostles were written during the second half of the 1st 
century CE. The context is that of the Judaic Hellenic world. The early church had taken its first catholic steps, despite the severe persecutions and brutal executions during the reign of Domitian (81-96 CE) and the Jews had to reorganise themselves under Pharisee leadership. Serious conflicts arose between the Jewish and Hellenistic worlds and within the growing Christian community; adherents to the new faith had to be accommodated from all sectors of the community. What were the contextual issues and how does the gospel address these?

Thus, even before tackling exegesis of a particular biblical text, it is possible for exegetes to construct an imaginary social context which may have produced the text. Imagining themselves into this context may result in a meaningful and coherent hermeneutical exercise.

Still deeply aware of the social context in which biblical texts were produced, Andries van Aarde (1988b:829-846) turns to Jesus. What did the world in which Jesus was born and bred, in which he lived, taught and died, look like? Jesus has to be studied in the context of the eastern Mediterranean world during the time when the New Testament came into being, that is, Palestine under Roman rule, but also deeply under the influence of Hellenistic thought and culture. This society was structured by some important ideological powers that determined the different social relationships, namely: economy, politics, family life and religion. In analysing these categories, Van Aarde (1988b:840-842) realises that modern notions of rich-poor in terms of 20th century capitalism of the developed world is vastly different from those of a 1st century citizen in the eastern Mediterranean world.

In the first place, the poor happened to be under those who were for some reason or another 'unclean'. A tax-collector, who performed a disgraceful task, was, despite all his riches, labelled poor. But in the second place, the family was the most important and most central social entity. Everything revolved around the family. Family relationships and to be securely embedded into a family were more important than anything else. If disaster struck, one could always rely on the family for help. In this sense, rich and poor were defined not only in terms of economic or monetary means, but in terms of family support. Thus, poor was not an economic category in the first place, but the poor were those people who did not belong to a family and had no societal resources. Given the strong patriarchal orientation of the time and the dependence of the family on its head, the patriarch, the poor had no-one else to rely on but God. In the 1st century Palestine, Jesus is to be found among the social outcasts who relies on God, his heavenly Father.

This article (1988b:844-845) also aims to make it clear that the gospels cannot serve as liberation manifestos as expressed in political terms like 'the privilege of the oppressed poor'. However, perhaps without realising it directly, Van Aarde's research into the historical Jesus was initiated. For from this point further, just as he applied himself diligently to narrative theories, Van Aarde would now turn his attention to models of social scientific criticism.

Biblical hermeneutics should always keep in mind the cultural distance between ancient and modern cultures, as well as mutual cultures within a particular period (1993b:516). Taking a look at advanced agrarian societies in 1st century Palestine, Van Aarde (1993b:515-545) illuminates the intricate social relationships of the time. Now, even more than previously, it becomes clear that not economy, but the family was the dominant institution in the society. However, a once predominant agrarian society had developed at the time of 1st century Palestine and became much more differentiated and stratified than before. During this transitory phase kinship and family ties were put under some stress, although, the interests of the family would not vanish completely yet. Instead, family relationships were absorbed into the broader societal structures, where they developed into an ideology. These societal structures were organised hierarchically and consisted of only two classes: the few elite, the powerful and the masses, those without power, usually the workers or the peasants. There was no middleclass. Between the elite and the masses existed a kind of reciprocal relationship, best described as a patron-client agreement. Patrons protected the clients and the clients were dependent of the patrons. Thus, it appears that the tight-knit familial bonds of the agrarian society have now been extended to a new relationship that functioned as an imaginary family or fictive kinship groups that were bound to one another by a shared solidarity (1993b:536). A group that gathered around a particular patron, called themselves his followers, or his disciples. Most probably the disciple circles of Jesus, as well as of John the Baptist, functioned as imaginary families. However, in the case of Jesus it appears that the 'clients' mostly consisted of the marginalised of society, the unclean, the displaced ones.

Once again, the result of the research is a monograph: Kultuurhistoriese Agtergrond van die Nuwe Testament. Die Eerste-eeuse Mediterreense Sosiale Konteks (Van Aarde 1994a) [The Cultural Historical Background of the New Testament. The First Century Mediterranean Social Context]. The aim is to provide modern readers with information regarding the social context of the area surrounding the Mediterranean Sea during the beginning of the New Testament. Van Aarde starts with the Maccabean War (2nd century BC) until the Bar-Kochba insurrection (2nd century AD) (1994a:9-62), thereby conveying something of the social dynamics behind the cultural history of the New Testament. He gives an overview of the Hellenistic-Roman presence in Palestine and offers some background to the religious beliefs, philosophies and cultural practices (1994a:63-86). The issues that were raised in the articles, are systemised and elaborated in the book, especially from Chapter 3, part 2 (1994a:86-130). Consequently, he discusses the many movements, groups, streams of thought, traditions and conflict within 1st century Palestine. Interpretation of the New Testament requires of the exegete to take all the larger structures of the Mediterranean 
society into account, like the political regime and economic exploitation of the Roman Empire, as well as the smaller units like kinship that came under pressure within Palestine as an advanced agrarian society.

Here a new, or should one rather say, an old world is opened. Andries van Aarde dares the modern exegete to explore a different way of life, a different mode of thought. Yet the hermeneutical exercise does not require merely cognisance of a strange and different word; it demands putting on a different 'think cap' altogether. Only then, one can imagine how 'the world goes round'.

\section{Jesus from the side}

It appears that Andries van Aarde's interests in both narrative and social scientific criticism paved the way for thorough research into the historical Jesus. Also, by now, Van Aarde plays a lively part in the so-called 'third quest' for the historical Jesus. However, up to the $90 \mathrm{~s}$, this is a debate mainly among scholars of the United States; Van Aarde is the only South African who openly supports this research and even partakes in discussions on the subject.

In 1993 (Van Aarde 1993a:397-423, 1993c:942-962), two articles are published in HTS Teologiese Studies/Theological Studies that give an indication of the Jesus research in South Africa since 1980, from Andrie du Toit, to Willem Vorster, to Andries van Aarde. The latter article was initiated by a research project (1992-1993) at the Institute for Ecumenical and Cultural Research in Collegeville, Minnesota, titled The epistemic status of New Testament and the emancipatory living of the historical Jesus in engaged hermeneutics. Engaged hermeneutics proposes engagement between theologians from the developed and the developing worlds. Theologians from the developed world often follow the traditional European academic approach to the canon, which is often irrelevant for the poor and oppressed countries elsewhere, whereas scholars from the developing world choose for the option of liberation-theology to serve their own needs. Where may the common ground for engagement be found? According to Van Aarde, not in the canon, but in the historical Jesus.

Taking cues from the gospels and from the 1st century Mediterranean world, Andries van Aarde proceeds to construct an 'ideal type' of Jesus of Nazareth. In terms of Max Weber's understanding, this 'ideal type' is not a depiction or hypothesis of reality, but a theoretical construct (cf. also 1994c:592, 1995:332, 1996:487, 2002:434), an imaginative sociological 'ideal type'.

Consequently, Van Aarde (1993c:946-947, cf. 1996:477) investigates traditions concerning Jesus' birth and the relationship with his family and draws the following portrayal of the historical Jesus: he lived in 1st century Herodian Palestine, a world where family interests were ideologically conditioned. Strained family relationships, his sharp critique of the patriarchal family and his trust in God as his Abba become noticeable (cf. 1995:330, 1996:487). Jesus seems to redefine the kingdom of God in terms of a brokerless household (Van Aarde 1993c:947, 951), where family members have direct access to God, the Father without the usual intercessions of the patriarchal head of the family. Thus, Jesus does not see the kingdom of God as an apocalyptic event, or comparable to earthly kingdoms. He envisages the kingdom of God as a household where strained relationships are "healed by means of "politics of compassion" and God's unmediated presence' (Van Aarde 1995:330).

A further question that has to be investigated is the matter of Jesus' baptism. Usually baptism is a ceremonial or ritual event in order to heal 'sinful sickness' (Van Aarde 1993c:952) or to remove certain stigmas attached to people, for example, being a fatherless son. The picture becomes even clearer as Van Aarde realises Jesus' special concern for the 'nobodies' in the society, women, children, prostitutes, tax collectors and so forth. By baptism Jesus is healed from 'sinful sickness', perhaps he was initially a follower of John the Baptist, but then broke away and started his own ministry of 'healed healers' who heal and forgive sinners (Van Aarde 1993c:952, 1995:330). The alternative wisdom of the 'ethos of compassion' was regarded as subversive to the temple ideology and brought him into disfavour with the religious leaders of his time, the Pharisees and the Sadducees. Eventually, like a criminal he was crucified by the Roman procurator. 'No family or fictive family took care of his body - and so Jesus of Nazareth died as he was born - a nobody among nobodies' (Van Aarde 1995:330).

These views Van Aarde would publish some years later in a sensational (even notorious) book, Fatherless in Galilee: Jesus as child of God (2001). Andries van Aarde is the first Afrikaans speaking South African to write a book that critically examines the life and history of Jesus of Nazareth (Le Roux 2002:77). This compels the reader to think historically, to penetrate to the earliest attestations of Jesus, to appreciate Jesus as someone from the 1st century Mediterranean world and to see a full picture of his life as human being (Le Roux 2002:97).

Andries van Aarde's understanding of the historical Jesus has been shaped through the many years that he was involved with the Context Group and Jesus Seminar. He shares many of their ideas and methods and has a special high esteem for John Dominic Crossan (cf. e.g. Van Aarde 2001:30-32, 62-63, 65-71, 168-169, 188-190). However, he takes his own point of departure, namely those traditions that point to Jesus as a fatherless son $(2011: 72,77)$, supported by an 'excursus' into a post-Easter Joseph trajectory (2001:82-118). Uncovering one layer after the other, Van Aarde comes closer to the historical Jesus. Research confirms that Jesus grew up as a fatherless son. He came from a peasant farming community of Herodian Galilee. He displayed a remarkable affinity towards the outcasts and marginalised of the society and was considered as a 'healer' by them. Towards the temple and imperial hierarchy, he was critical and rejected their modes of operating. He communicated his vision of the kingdom of God by means parables, metaphorical and proverbial expressions and the favourites are not the elite of the society, but the poor and rejected members. 
Van Aarde's (2001:1-32) investigation is historical by nature, but definitely not in the positivist sense of historicism. He agrees with many of his predecessors that a grip on the historical Jesus is impossible. The closest one can get to the 'historical Jesus' is by means of a multidisciplinary and interdisciplinary approach, therefore, the traditional historical criticism has to be supplemented by insights from especially social scientific criticism. Thus, Van Aarde calls his 'ideal' construct of Jesus, 'Jesus from the side' (Van Aarde 2001:38).

\section{What does this mean?}

Up to now, that is, the 1990s, research regarding the historical Jesus, was either 'from above' or 'from below' (Van Aarde 1993c:953, cf.1994c:362, 1994d:589, 2001:38). Christology 'from above' that took shape after Constantine, reflect traditions of political power and hierarchy and are characterised by many conciliar debates regarding the 'two natures' of Christ. Then came the 'Enlightenment' with its trust in human reason and which, especially during the 18th century, had an almost devastating effect on the Church. Consequently a Christology 'from below' became important for theologians of the 19th and 20th centuries, which focused increasingly on the humanity of Jesus. However, both these Christologies, from above and from below, indicate a vertical direction. This was not the way in which Jesus was seen by his own contemporaries or earliest followers. They regarded him as equal, regarded him from a horizontal perspective, therefore, 'from the side'. Thus, Van Aarde's ideal construct of the historical Jesus 'from the side' takes into account the social processes in terms of which Jesus was either honoured or put to shame by his contemporaries of the community in which he lived - and died.

Jesus 'from the side' has far reaching implications for the South African theological scene, as well globally. The concern of the project that initiated the paper mentioned previously (1993c) was 'engaged hermeneutics' and the engagement implied is between the traditional theology of theologians from the developed world and contextual theology of the developing world (cf. 1994c:345-367, 1994d:575-596). Theologians on both sides regard the Bible, especially the New Testament, as hermeneutical source (1994d:577). However, theology from the developed world is permeated by the vertical structure of Christology 'from above' as well as 'from below' (1994a:362). Furthermore, the imperialism and colonialism of the developed world onto the developing world was not received favourably by theologians from the latter. Consequently, contextual theology from the developing world often became 'designed' to shake off the manipulative power-invested hold from the developed world. Is it possible to find an alternative design for engaged hermeneutics?

Contextual theology of both the developed and developing world is concerned about the 'economically poor and politically oppressed ... the non-person ... the peripheral person' (Van Aarde 1994c:349). Therefore, Jesus from the side provides the ideal ground for engaged hermeneutics and becomes the proverbial 'answer to the question'. Research into the historical Jesus reveals that Jesus of history continues in Jesus of faith (Van Aarde 1995:329, cf. 2003:549). The Christian religion is not a book religion, but models its belief patterns on the words and deeds of Jesus of Nazareth. Therefore, memory of the Jesus of history as manifestation of God, would make it clear to understand what 'emancipatory living' means. Thus, Jesus the Jew living in 1st century Herodian Palestine whose life started and ended as a 'nobody', is the ideal hermeneutical bridge between the developed and developing world, by providing not a theology from 'above' or 'below', but from the side.

Of course, engaged hermeneutics is not relevant to contextual theology of the developed and developing world only, it pertains to existential and ethical issues of society at large: matters concerning gender, race, sexual orientation, age, social and religious orientation:

As the living symbol of God's unmediated presence, the historical Jesus set people free and, as the risen Christ and Kyrios (Lord) he still sets people ... free from distorted relationships with oneself, others and God. Christian ethics is not an abstract ideology but it is based on the humanness and humaneness of the Jesus of history.

(Van Aarde 2003:550)

\section{Concluding remarks}

Andries van Aarde has done pioneering research by appropriating theories and methodologies of fields from outside theology to reading biblical texts. Studies like these are interesting, even entertaining, but often run the risk of remaining theoretical endeavours without any practical value, however. Andries van Aarde convincingly demonstrated that this is not the case. On the one hand, he strips the biblical texts from their usual dogma. On the other hand and most importantly, he holds these texts in deep respect by appreciating their narrative art as well as the socio-cultural context in which they originated. His compelling portrayal of the historical Jesus has far reaching implications for further academic studies, as well as for the practical ministry of the church.

\section{References}

Le Roux, J.H., 2002, 'Andries van Aarde se vaderlose Jesus', HTS Teologiese Studies/ Theological Studies 58(1), 77-99.

Van Aarde, A.G., 1983, " $\mathrm{n}$ Literatuur-teorietiese benadering tot die Evangelies', HTS Teologiese Studies/Theological Studies 38(4), 58-82.

Van Aarde, A.G., 1984, 'Die weg van die teks na die preek: Die verkondiging van Nuwe Testament as kommunikasie-gebeure', HTS Teologiese Studies/ Theological Studies 40(2), 123-146.

Van Aarde, A.G., 1985, "Narrative point of view and the "temporal function" of the Old Testament in Matthew's gospel', HTS Teologiese Studies/Theological Studies 41(2), 272-289.

Van Aarde, A.G., 1988a, 'Narrative point of view: An ideological reading of Luke 12:35-48', Neotestamentica 22, 231-250.

Van Aarde, A.G., 1988b, 'Jesus en die sosiaal-veragtes', HTS Teologiese Studies/ Theological Studies 44(4), 829-846.

Van Aarde, A.G., 1993a, 'Recent developments in South African Jesus research: From Andrie du Toit to Willem Voster', HTS Teologiese Studies/Theological Studies 48(3\&4), 397-423.

Van Aarde, A.G., 1993b, 'Aspekte van die sosiale stratifikasie van die ontwikkelde argrariese samelewing in die eerste-eeuse Palestina', HTS Teologiese Studies/ Theological Studies 49 (3), 515-545.

Van Aarde, A.G., 1993c, 'Recent developments in South African Jesus research: From Willem Voster to Andries van Aarde', HTS Teologiese Studies/Theological Studies 49(4), 942-962. 
Van Aarde, A.G., 1994a, 'God with us': The dominant perspective in Matthew's story and other essays, Gutenberg Publishers, Pretoria.

Van Aarde, A.G., 1994b, Kultuurhistoriese agtergrond van die Nuwe Testament: Die eerste-eeuse Mediterreense sosiale wêreld, Kital Uitgewers, Pretoria.

Van Aarde, A.G., 1994c, 'Kultuurimperialisme as ' $n$ hermeneutiese dilemma: Eerstewêreldse en Derde-wêreldse perspektiewe op Jesus as die Seun van God', HTS Teologiese Studies/Theological Studies 50(1\&2), 345-367.

Van Aarde, A.G., 1994d, 'The epistemic status of the New Testament and the emancipatory living of the historical Jesus in engaged hermeneutics', Neotestamentica 28(2), 575-596.

Van Aarde, A.G., 1995, "The "third quest" for the historical Jesus - where should it begin: With Jesus' relationship to the Baptiser or with the nativity traditions?', Neotestamentica 29, 325-356.

Van Aarde, A.G., 1996, 'Die historiese ondersoek van Jesus van Nasaret in perspektief', HTS Teologiese Studies/Theological Studies 52(2\&3), 476-500.

Van Aarde, A.G., 2001, Fatherless in Galilee: Jesus as Child of God, Trinity Press International, Harrisburg, PA.

Van Aarde, A.G., 2002, 'Methods and models in the quest for the historical Jesus: Historical criticism and/or social scientific criticism', HTS Teologiese Studies/ Theological Studies 58(2), 419-439.

Van Aarde, A.G., 2003, 'Does historical Jesus research have a future?', Verbum et Ecclesia 24(2), 533-556.

Van Aarde, A.G., 2006a, 'Genre en plot-georiënteerde narratief-kritiese eksegese van Evangeliemateriaal. Inleiding tot narratiewe kritiek', HTS Teologiese Studies/ Theologica Studies 52(2), 657-677.

Van Aarde, A.G., 2006b, 'Vertellersperspektiefanalise van Nuwe-Testamentiese tekste', HTS Teologiese Studies/Theological Studies 62(3), 1111-1143.

\section{APPENDIX 1}

\section{Andries Gideon van Aarde - Curriculum Vitae}

\section{Born}

25 April 1951, Pretoria, South Africa

\section{Education}

D.Litt. (Ancient Languages: Greek), 2005, Dissertation: 'The Infancy Gospel of Thomas as a heroic myth of the child-god Jesus within the context of Ebionite early Christianity'. Ph.D. (History of Ancient Culture), 2000, Dissertation: 'Historicization of myth: The metaphor "Son of God" and its Hellenistic-Semitic and Graeco-Roman Background'.

D.D. (New Testament studies), 1982, Dissertation: 'God-with-us: The dominant Perspective in Matthew's story'.

M.A. (Semitic Languages), 1978, Dissertation: 'Macarism-Series in the New Testament, Jesus Sirach, and 2 Slavonic Enoch: A form-critical study'.

B.A. Honours (Greek and Semitic Languages Combined), 1977

B.D. (Theology), 1974.

B.A. (Major: Greek and Semitic Languages; Minors: Philosophy, German, French, Latin), 1977.

\section{Professional positions}

Senior Research Fellow, Unit of Advanced Studies, University of Pretoria, 2010 Honorary Professor, Department of New Testament Studies, Faculty of Theology, University of Pretoria, 2009 -

Chairperson of the Executive of the Board of Directors of the To Care Foundation for vulnerable people (a NGO and NPO Article 21 company which focuses on corporate fundraising for poverty alleviation, professional social services and community fundraising for poverty alleviation,

2009 -Research Manager, Faculty of Theology, University of Pretoria, January 20002004 Chairperson of the Department of New Testament, Faculty of Theology (Section A), University of Pretoria, 1989-1999

Full Professor, 1989 -

Associate Professor of New Testament, Faculty of Theology, University of Pretoria, 1984-1988

Senior Lecturer, Biblical Studies: specialisation: Old Testament, Faculty of Theology, University of Pretoria, 1980-1983

Lecturer of Hellenistic Greek, Faculty of Humanities, University of Pretoria, 1979-1980 Part-time lecturer of New Testament Greek and Biblical Studies at the Africa Institute for Missiology (accredited by the University of Pretoria), 1985-1999 Ordained pastor, Netherdutch Reformed Church of Africa, 1974 -

Editor: HTS Theological Studies/Teologiese Studies, 1985 -

\section{Professional memberships}

The South African Society of Patristic and Byzantine Studies
Society of Biblical Literature (USA)

New Testament Society of South Africa

Societas Novi Testamenti Studiorum, Co-Chair of Matthew Subgroup 2000-2005

The Jesus Seminar of the Westar Institute (USA)

The Context Group: A Project on the Bible and its Cultural Environment (USA)

Catholic Biblical Association of America

\section{Previous professional activities}

Resident Scholar: Institute for Ecumenical and Cultural Studies (St John's University, Collegeville, MN, USA), 1992-1993

Visiting Scholar: Graduate Theological Union (University of California, Berkeley, CA, USA), 1997-1998

Visiting Scholar: Tantur Institute for Ecumenical and Theological Studies, Jerusalem (Israel), October 1999-January 2000

Resident Scholar: St Deiniol's Library, Hawarden (Wales), February 2000

\section{International guest professor}

St Mary's College, University of St Andrews (Scotland), February 2000 King's College, University of London (UK), February 2000 United Faculty of Theology (Jesuit Theological College), Trinity College Theological School, The Theological Hall of the Uniting Church of Australia, Melbourne (Australia), April 2000

Catholic University of Australia, Melbourne, April 2000

Catholic University of Australia, Brisbane, April 2000

Katholieke Universiteit Nijmegen (the Netherlands), July-September 2001

Katholieke Universiteit Leuven (Belgium), March 2003

Otterbein College, Westerville, Ohio (USA), January 2004

McCormick Theological Seminary, Chicago (USA), January 2004

Evangelical Theological Seminary, Cairo (Egypt), September-December 2004

\section{Papers read at international conferences}

Münster (Germany 1993); Dublin (Ireland) 1996; Leuven (Belgium) 1988 and 1996; Sheffield (UK), 1988; Vienna (Austria) 1990; San Francisco (USA), 1992; Birmingham (UK) 1997; Santa Rosa, CA (USA) 1996, 1997 and 1998; Collegeville, MN (USA) 1992 and 1993; Portland, OR (USA) 1991, 1992 and 1996; Tützing (Germany) 1999; Pretoria (SNTS International Meeting) 1999; Jerusalem 2000; Pretoria (The Context Group) 2001; Montréal, QC Canada (SNTS International Meeting) 2001; SNTS Durham (UK) 2001; SNTS International Meeting Barcelona 2002, Bonn 2003; SBL Philadelphia 2007, Boston 2008, New Orleans 2009

\section{Awards and grants Centre for Science Development of the Human Research Council of South Africa}

1990, 1993, 1996 - Travel Grants to attend international conferences in Sheffield, Münster and Leuven

1990 - Research Fellow of Visiting Professor J.H. Elliott (University of San Francisco) 1991 - 1992 - Ad Hoc Grant for research on the Separation of Judaism and Christianity 1995 - Research Fellow of Visiting Professor M.J. Borg (State University of Oregon, Corvallis)

1997 - Research Fellow of Visiting Professor Carolyn Osiek (Catholic Theological Union Chicago

\section{National Research Foundation}

1999 - 2000 - Senior Research Grant (for project: The Joseph Trajectory in the Old Testament, Intertestamental Literature, the New Testament, and Patristic Literature 2010 - NRF Rating Incentive

\section{University of Pretoria}

1993 - 1995 - Excellent Academic Achievement 
1996 - 1998 - Excellent Academic Achievement 1999 - 2001 - Excellent Academic Achievement 2002 - 2004 - Excellent Academic Achievement 2003 - 2005 - Mellon Foundation Mentor Programme Award 2003 - International Exchange Programme: Katholieke Universiteit Leuven and the University of Pretoria

\section{Miscellaneous}

2001 - 2004 - Mellon Mentorship Award

2004 - United States of America's Endowment for the Humanities (Otterbein College Westerville, $\mathrm{OH}$ (USA)

2007 - The Netherdutch Reformed Church of Africa's HCM Fourie Academy Award 2008 - The South African Academy for Science and Arts: Van Drimmelen Award for Religion

\section{Post-graduate students}

Supervisor of 20 completed doctoral dissertations and 7 masters dissertations

\section{Scientific publications}

Author of 6 monographs

Editor of 9 monographs in Supplement Series

Author of 25 chapters in books

Author (or co-author) of 182 scientific articles in accredited journals

Author of 70 popular-scientific articles

\section{Articles in peer-reviewed journals}

1978, 'Moderne semantiek en formele homiletiek', HTS Teologiese Studies/Theological Studies 34(1\&2), 41-56.

1978, 'Die vraag na Bybelse gronde vir die onderskeiding in bearbeidingswyse tussen heidensending en die arbeid onder "buitekerklikes": Enkele Nuwe-Testamentiese riglyne', HTS Teologiese Studies/Theological Studies 34(1\&2), 57-75.

1980, 'Nuwere benadering tot Gattungsforschung', HTS Teologiese Studies/ Theological Studies 36(1\&2), 58-73.

1980, “"Betekenis" en "gebruik" in die makarismereeks (Matt 5:3-10)', HTS Teologiese Studies/Theological Studies 36(3\&4), 1-28.

1980, 'Bruikbaarheid van aktante-analise vir die eksegese van Sinoptiese Tekste', HTS Teologiese Studies/Theological Studies 36(3\&4), 29-49.

1981, 'Kritiek op die fundamentalisme: 'n Vorm van teologiese liberalisme?', HTS Teologiese Studies/Theological Studies 37(4), 6-21.

1982, 'Ondersoek na die Nuwe-Testamentiese makarisme en makarismereeks as Gattung', HTS Teologiese Studies/Theological Studies 38(1), 36-52.

1982, 'Matthew's portrayal of the disciples and the structure of Matthew 13:5317:27', Neotestamentica 16, 21-34.

1982, 'Discourse analysis of the Greek text of Matthew 13:53-17:27', Neotestamentica 16, 1-17. (Addendum to Neotestamentica 16)

1983, 'Vertellersperspektief-analise: 'n Literatuurteoretiese benadering tot die Evangelies', HTS Teologiese Studies/Theological Studies 38(4), 58-82.

1984, 'Verlede en hede op die gebied van die Matteusnavorsing: 'n Oorsig van die verskillende interpretasiemodelle', Scriptura 11, 1-49.

1984, 'Die weg van die teks na die preek: Die verkondiging van die Nuwe Testament as kommunikasie-gebeurtenis', HTS Teologiese Studies/Theological Studies 40(2), 145-147.

1984, "Verbondstruktuur" in die Nuwe Testament: 'n Terreinverkenning met die oog op die debat oor die verhouding kinderdoop-verbond', HTS Teologiese Studies/ Theological Studies 40(3), 28-55.

1985, "Narrative point of view and the "temporal function" of the Old Testament in Matthew's gospel" (original printed in Afrikaans), HTS Teologiese Studies/Theological Studies 41(2), 272-289.

1985, 'Redaksioneel: Predikantevergadering 1985 en die gesag en funksie van die Bybel en belydenisskrifte', HTS Teologiese Studies/Theological Studies 41(3), 337-338. 1985 , 'The use of Scripture: Principles in hermeneutics' (original printed in Afrikaans) HTS Teologiese Studies/Theological Studies 41(4), 547-578.

1985 , 'Die outeurskapsvraag van die Johannesevangelie met die oog op interpretasie of resepsie', Skrif \& Kerk 6, 45-62.

1986, 'Resensensie van Engelbrecht, E., "Sending en geregtigheid in die Matteusevangelie"', HTS Teologiese Studies/Theological Studies 42(1), 170-176.

1986, 'The "Wirkungsgeschichte" of Matthew 28:16-20 in "volkschristianisierende" missiology"' (original printed in Afrikaans), HTS Teologiese Studies/Theological Studies 42(1), 77-93.

1986, 'The miraculous multiplication of loaves (Mt 14:13-21 en par): Historical criticism in perspective"' (original printed in Afrikaans), HTS Teologiese Studies/ Theological Studies 42(2), 229-256.
1986, 'The parables of Jesus: Classification and preaching' (original printed in Afrikaans), HTS Teologiese Studies/Theological Studies 41(3), 441-457.

1986, 'Demonology in New Testament times' (original printed in Afrikaans), HTS Teologiese Studies/Theological Studies 41(3), 547-563.

1986, 'Rudolf Bultmann en Karl Barth in herinnering', HTS Teologiese Studies/ Theological Studies 42(4), 649-651.

1986, (co-author, Pelser, G.M.M.), 'Verslag van die 49ste algemene vergadering van die CBA en die 41ste algemene vergadering van die SNTS', HTS Teologiese Studies/ Theological Studies 42(4), 630-648.

1987, 'Immanuel as die geïnkarneerde tora: Funksionele Jesusbenaminge in die Matteusevangelie as vertelling', HTS Teologiese Studies/Theological Studies 43(1\&2), 242-277.

1987, 'Thoughts on the beginnings of the church as a history of reconciling Diversity' (original printed in Afrikaans), HTS Teologiese Studies/Theological Studies 43(3), 325-351.

1987, Resensie van Van Zyl, H.C., "Diachroniese en sinchroniese ondersoek met besondere verwysing na kerklike dissipline', HTS Teologiese Studies/Theological Studies 43(4), 776-787.

1988, (co-author, Pelser, G.M.M.), 'Verslag van die 42ste jaarlikse kongres van die Studiorum Novi Testamenti Societas gehou by die Georg-August Universiteit Göttingen, 24-28 Augustus 1987', HTS Teologiese Studies/Theological Studies 44(1) 178-202.

1988, 'Die werklikheidsbetrokkenheid van teologiese uitsprake', HTS Teologiese Studies/ Theological Studies 44(1), 1-5.

1988, 'Narrative point of view: An ideological reading of Luke 12:35-48', Neotestamentica 22, 231-250.

1988, 'Jesus en die sosiaal-veragtes', HTS Teologiese Studies/Theological Studies 44(4), 829-846

1989, 'Resensie van Scheffler, E.H., "Suffering in Luke's Gospel"', HTS Teologiese Studies/Theological Studies 45(1), 183-190.

1989, 'Verslag van die 1988 International Meeting Society of Biblical Literature, Sheffield 1988', HTS Teologiese Studies/Theological Studies 45(1), 146-180.

1989, 'Redaksionele beleid van die Hervormde Teologiese Studies', HTS Teologiese Studies/Theological Studies 45(1), 1-2.

1989 " "Hgerthe apo tōn nekrōn" (Mt 28:7): A textual evidence on the separation of Judaism and Christianity', Neotestamentica 23, 219-233.

1989, 'The foundation of the unity of the church in the New Testament and the quest for unity today' (original printed in Afrikaans), HTS Teologiese Studies/Theological Studies 45(2), 461-475.

1989, (co-author, Van Eck, E.), 'Narratological analysis of Mark 12:1-12: The plot of the Gospel of Mark in a nutshell', HTS Teologiese Studies/Theological Studies 45(4), 778-800.

1990, 'Resonance and reception: Interpreting Mt 17:24-27 in context', Scriptura 29 , $1-12$.

1989, 'Redaksioneel', HTS Teologiese Studies/Theological Studies 45(4), 739

1990, 'Die heiligheid van die kerk teen die agtergrond van die breuk kerk-Sinagoge', In die Skriflig 24(3), 251-263.

1990, (co-author, Strijdom, J.M.), 'Markus 16:1-8 in die konteks van 'n konstruksie van die Markaanse gemeente', HTS Teologiese Studies/Theological Studies 46(1\&2), 153-189.

1990, 'HTS - Ortografiese vereistes', HTS Teologiese Studies/Theological Studies 46(1\&2), 3-13.

1990, 'Gesprek tussen teoloë en filosowe oor postmoderniteit', HTS Teologiese Studies/Theological Studies 46(3), 265-266.

1990, 'Holisme as 'n postmodernistiese filosofie in teologiese lig', HTS Teologiese Studies/Theological Studies 46(3), 293-311.

1991, (co-author, Van Staden, P.), 'Social description or social-scientific interpretation? Survey of modern scholarship', HTS Teologiese Studies/Theological Studies 47(1) $55-87$.

1991, (co-author, Steenekamp, N.J.S.), 'Deconstruction and biblical hermeneutics', (original printed in Afrikaans), HTS Teologiese Studies/Theological Studies 47(2), 473-486.

1991, (co-author, Vledder, E.J.), 'A holistic view of the Holy Spirit as agent of ethical responsibility: This view experienced as exiting in Romans 8, but alarming in 1 Corinthians 12', HTS Teologiese Studies/Theological Studies 47(2), 503-525.

1991, (co-author, Oliver, W.H.), 'The community of faith as dwelling-place of the Father: Basileia tou Theou as "household of God" in the Johannine farewell discourse(s)', Neotestamenttica 25(2), 379-400.

1991, 'A New Testament perspective on children', (original printed in Afrikaans), HTS Teologiese Studies/Theological Studies 47(3), 685-715.

1991, (co-author, Boshoff, P.B.), 'Theory and practice of preaching according to Walter Schmithals', (original printed in Afrikaans), HTS Teologiese Studies/Theological Studies 47(4), 901-919.

1991 (co-author, Van Niekerk, B.), 'Holistiese verstaan teenoor analitiese verstaan in Bybelse hermeneutiek', HTS Teologiese Studies/Theological Studies 47(4), 1042-1057. 1992, 'J H J A Geyvenstein - Professor 1917-1945: Paving the way for critical an historical understanding of the New Testament at the University of Pretoria' (origina printed in Afrikaans), HTS Teologiese Studies/Theological Studies 48(1\&2), 139-158.

1992, 'A S Geyser - lecturer in theology 1946-1961', (original printed in Afrikaans), HTS Teologiese Studies/Theological Studies 48(1\&2), 159-182. 
1992, 'How does one speak about/of God? Theological idioms in the past and Present', (original printed in Afrikaans), HTS Teologiese Studies/Theological Studies 48(3\&4), 957-976.

1993, 'In memoriam: Professor Willem S Vorster', HTS Teologiese Studies/Theological Studies 49(3), 383-384.

1993, 'Recent developments in South African Jesus research: From Andrie du Toit to Willem Vorster', HTS Teologiese Studies/Theological Studies 48(3\&4), 397-423.

1993 , 'Aspects of the social stratification of the advanced agrarian society in firstcentury Palestine', (original printed in Afrikaans), HTS Teologiese Studies/Theologica Studies 48(3\&4), 515-545.

1993, (co-author, Nel, G.C.J.), 'The "postmodern" stamp in the hermeneutics of the New Testament' (original printed in Afrikaans), HTS Teologiese Studies/Theological Studies 48(3\&4), 609-620.

1993, 'Etiek agter mede-outeurskap', HTS Teologiese Studies/Theological Studies 49(4), 688-689.

1993, 'Recent developments in South African Jesus research: From Willem Voster to Andries van Aarde', HTS Teologiese Studies/Theological Studies 49(4), 942-962.

1994, ' $n$ Redaksionele voorwoord tot die Hervormde Teologiese Studies se Goue Jubileum', HTS Teologiese Studies/Theological Studies 50(1\&2), 1-5.

1994, 'Reeksvoorwoord', HTS Teologiese Studies/Theological Studies Supplementum 6, iii.

1994, 'Kultuurimperialisme as ' $n$ hermeneutiese dilemma: Eerste-wereldse en Derde wereldse perskpektiewe op Jesus as die Seun van God', HTS Teologiese Studies/ Theological Studies 50(1\&2), 354-367.

1994, 'Tracking the pathways opened by Willem Vorster in historical Jesus research', Neotestamentica (Special Edition) 28(3), 235-251.

1994, (co-author, Nel, G.C.J.), 'Etiek van Jesus in die lig van Q: Eskatologies of wysheidsteologies begrond?', HTS Teologiese Studies/Theological Studies 50(4) 936-952.

1994, (co-author, Vledder, E.J.), 'The social stratification of the Matthean Community', Neotestamentica 28(2), 511-522.

1994, (co-author, Nel, G.C.J.), 'Die "postmoderne" stempel in die Nuwe-Testamentiese hermeneutiek', HTS Teologiese Studies/Theological Studies 49(3), 609-620.

1994, 'The epistemic status of the New Testament and the emancipatory living of the historical Jesus in engaged hermeneutics', Neotestamentica 28(2), 575-596.

1994, (co-author, Volschenk, G.J.), 'Sistematies verwronge kommunikasie in Lukas 14:1-6: Die dialekties-kritiese teorie van Jürgen Habermas krities bespreek', HTS Teologiese Studies/Theological Studies 50(3), 812-840.

1995, (Du Toit, B.A., resensent van Van Aarde, A.G. 1994), 'Kultuurhistoriese agtergrond van die Nuwe Testament: Die eerste-eeuse Mediterreense sosiale konteks', HTS Teologiese Studies/Theological Studies 51(1), 263-264.

1995, 'Church and theology on a mesoparadigmatic shift towards the third Millennium' (original printed in Afrikaans), HTS Teologiese Studies/Theological Studies 51(2), 13-38.

1995, 'Church and theology heading towards the third millennium: Thoughts on the contextualization of dialectical theology within a plural society', (original printed in Afrikaans), HTS Teologiese Studies/Theological Studies 51(1), 39-64.

1995, 'The "third quest" for the historical Jesus - where should it begin: With Jesus' relationship to the Baptiser, or with the nativity traditions?', Neotestamentica 29 325-356.

1995, 'The historical Jesus, the Jesus movement and the birth of the church', (original printed in Afrikaans), HTS Teologiese Studies/Theological Studies 51(3), 623-644.

1995, (co-author, Vledder, E.J.), 'The social location of the Matthean Community', HTS Teologiese Studies/Theological Studies 51(2), 388-408.

1995, (co-author, Nel, C.), 'Tendencies in the study of orality: Implications for the understanding of the Gospel of Matthew' (original printed in Afrikaans), HTS Teologiese Studies/Theological Studies 51(2), 409-437.

1995, 'Die menslikheid van die verskeidenheid in die kerk', HTS Teologiese Studies/ Theological Studies 51(3), 865-875.

1996, 'Historical Jesus research in perspective', (original printed in Afrikaans), HTS Teologiese Studies/Theological Studies 52(2\&3), 476-500.

1996, (co-author, Denton, R.), 'Jesus gesien deur die oë van 'n Marxis: In gesprek me Milan Macovec', HTS Teologiese Studies/Theological Studies 52(2\&3), 318-350.

1996, (co-author, Botma, A.), 'Die formule "en Christo" as basis van die Pauliniese ekklesiologie', HTS Teologiese Studies/Theological Studies 52(2\&3), 285-317.

1996, 'Kultuurkritiek, eerste-eeuse kulturele wysheid en die alternatiewe visie van Jesus van Nasaret', HTS Teologiese Studies/Theological Studies 52(4), 838-849.

1996, 'The Second Letter to the Thessalonians: Reread as pseudepigraph', The Journal of Higher Critical Studies 3(2), 237-266, [Reprinted in HTS Teologiese Studies/ Theological Studies 2000, 56(1), 105-136].

1996, 'Armoedekultuur: Die leefwêreld van die Nuwe Testament en die situasie in Suid-Afrika vandag', HTS Teologiese Studies/Theological Studies 52(4), 947-964.

1997, 'Social identity, status envy and Jesus' Abba', Pastoral Psychology 45(6), 451472

1997, (co-author, Van Zyl, S.), 'Die Lukaanse Jesusbeeld: In dialoog met Wilhelm Bousset se "Kyrios Christos"', HTS Teologiese Studies/Theological Studies 53(1\&2), 185-208.

1997, 'Side-notes from Graeco-Roman and Hellenistic-Semitic literature to the notion "adopted as God's child" (huiothesia), Acta Patristica et Byzantina 8, 150-172.
1997, "The notion "Son of God" in the Graeco-Roman and Hellenistic-Semitic Literature' (original printed in Afrikaans). HTS Teologiese Studies/Theological Studies 53(4), 1138-1161.

1997, 'The First Testament in the Gospel of Matthew', HTS Teologiese Studies/ Theological Studies 53(1\&2), 126-145.

1997/1998, 'Aanneming tot kind van God (huiothesia) by Paulus in Romeine 8 teen die agtergrond van die Jerusalemse tempelkultus se huweliksmaatreëls', Skrif en Kerk 18(2), 345-355; 19(1), 96-114.

1998, 'Matthew 27:45-53 and the turning of the tide in Israel's history', Biblical Theology Bulletin 28(1), 16-26, [reprinted in HTS Teologiese Studies/Theological Studies 1999/55 (2\&3), 671-692].

1998, 'Jesus' father: The quest for the historical Joseph', HTS Teologiese Studies/ Theological Studies 54(1\&2), 315-333.

1998, (co-author, Geyser, A.), 'Sosiale kruisigingsteks(te) van 110 Tempel 64.6-3: 'n Ondersoek na intertekstualiteit', HTS Teologiese Studies/Theological Studies 54(3\&4), 426-443.

1998, (co-author, Malan, G.J.), 'The day of the Lord in 2 Peter from the perspective of the sociology of knowledge', (original printed in Afrikaans), HTS Teologiese Studies/ Theological Studies 54(3\&4), 529-543.

1998, (co-author, Malan, G.J.), 'Rudolf Bultmann's programme of demythologizing applied to the concept of the day of the Lord in 2 Peter', (original in Afrikaans), HTS Teologiese Studies/Theological Studies 54(3\&4), 652-671.

1998, (co-author, Ayres, J.), 'Jesus - 'n geloofsgeneser?', HTS Teologiese Studies/ Theological Studies 54(3\&4), 687-711.

1998, (co-author, Thomas, A.), 'Samaria as belangeruimte in LukasHandelinge' HTS Teologiese Studies/Theological Studies 54(3\&4), 736-788.

1998, (co-author, Reinstorf, D.), 'Jesus' kingdom parables as metaphorical stories: A challenge to a conventional worldview', HTS Teologiese Studies/Theological Studies 54(3\&4), 603-622.

1998, 'Fatherless in first-century Mediterranean culture: The historical Jesus seen from the perspective of cross-cultural anthropology and cultural psychology', HTS Teologiese Studies/Theological Studies 55(1), 97-119.

1998, 'Dekonstrusie van dogma: 'n Eietydse ondersoek na die spore van die leer van die twee nature van Jesus', HTS Teologiese Studies/Theological Studies 55(2\&3), 437-470.

1998, 'The Spirit of God in the New Testament: Diverse witnesses', HTS 55(1), 221241.

1999, (co-author, Malan, G.J.), 'Invloed van die Mediterreense tydsbegrip op die betekenis van die dag van die Here in 2 Petrus', HTS Teologiese Studies/Theological Studies 55(1), 209-220.

1999, 'The historicity of the circle of the Twelve: All roads lead to Jerusalem', HTS Teologiese Studies/Theological Studies 55(2\&3), 795-826.

1999, 'Die relevansie van die historiese Jesus-ondersoek vir kerklike Teologie', HTS Teologiese Studies/Theological Studies 55(2\&3), 549-571.

1999, (co-author, Beukes, C.J.), 'C H Rautenbach, P S Dreyer en C K Oberholzer: Their legacy and the way ahead', (original printed in Afrikaans), HTS Teologiese Studies/ Theological Studies 55(1), 1-37.

1999, (co-author, Dreyer, Y.), 'The institutionalization of Jesus' charismatic authority: Indirect Christology-direct Christology', HTS Teologiese Studies/Theological Studies 56(2\&3), 697-722.

2000, 'The continued importance of Jesus', The Fourth R: An Advocate for Religious Literacy 13(1), 13-16.

2000, (co-authors, Botma, M.A. \& Koekemoer, J.H.), 'Onaanvaarbare verskeidenheid in Galasiërs: Ekklesia en sunagoge', HTS Teologiese Studies/Theological Studies 56(2\&3), 743-777.

2000, (co-author, Van Wyk, D.J.C. jr.), 'Twee versoenbare konstrukte in resente historiese Jesus-navorsing: John Dominic Crossan en Andries van Aarde', HTS Teologiese Studies/Theological Studies 56(2\&3), 795-813, 814-835.

2000 , 'Interpreting the doctrine of the virginal conception of Jesus', (original printed in Afrikaans), HTS Teologiese Studies/Theological Studies 56(4), 905-934.

2000, 'Understanding Jesus' healings', Scriptura 74, 223-236.

2000, 'Jesus and Joseph in Matthew's Gospel and other texts', Neotestamentica 35 $1-21$.

2000, 'Jesus and Perseus in Graeco-Roman literature', Acta Patristica et Byzantina 9, 188-201.

2001, (co-author, Groenewald, J.), 'Apocalypticism and millennialism: The relevance of the "thousand year reign" for today' (original printed in Afrikaans), HTS Teologiese Studies/Theological Studies 57(1\&2), 676-704.

2001, 'Die vaderlose Jesus', Fragmente. Tydskrif vir Filosofie en Kultuurkritiek 7, 91100

2001, 'Jesus - Kind van God, vaderloos in Galilea', Verbum et Ecclesia 22(2), 401-417. 2001, (co-author, Pelser, G.M.M.), 'An in-depth theological discussion', (origina printed in Afrikaans), HTS Teologiese Studies/Theological Studies 57(1\&2), 7-48.

2001, 'The cause of Jesus (Sache Jesu) as the canon behind the canon', HTS Teologiese Studies/Theological Studies 57(1\&2), 148-171.

2001, 'Millennialism, eschatology, and apocalypticism', (original printed in Afrikaans), HTS Teologiese Studies/Theological Studies 57(3\&4), 1158-1178.

2001, (co-author, Viljoen, D.A.), 'Die boek Openbaring - brandpunte in die teologiese debat', HTS Teologiese Studies/Theological Studies 57 (3\&4), 1288-1311. 
2002, "Matthew and apocalypticism as the "mother of Christian theology": Ernst Käsemann revisited', HTS Teologiese Studies/Theological Studies 58(1), 118-142.

2002, (co-author, Volschenk, G.J.), 'The historical quest for the land and land tenancy in Israel: The limitations of historical criticism', (original printed in Afrikaans), HTS Teologiese Studies/Theological Studies 58 (1), 212-324.

2002, 'Methods and models in the quest for the historical Jesus: Historical criticism and/or social scientific criticism?', HTS Teologiese Studies/Theological Studies 58(2), 419-439.

2002, (co-author, Reinstorf, D.), 'Reflections on Jesus' parables as metaphorical stories past and present', HTS Teologiese Studies/Theological Studies 58(2), 721-745.

2002, (co-author, Volkschenk, G.J.), 'A social scientific study of the significance of the jubilee in the New Testament', HTS Teologiese Studies/Theological Studies 58(2), 811-837.

2002, (co-author, Nel, G.C.J.), 'The Kingdom of God in Jesus' words: An apocalypticaleschatological or an ethical-eschatological concept?', (original printed in Afrikaans), HTS Teologiese Studies/Theological Studies 58(3), 1089-1112.

2002, 'Die "evangelie" van Paulus', Verbum et Ecclesia 23(2), 516-532.

2002, (co-author, Groenewald, J.), 'Early Christian baptism as a cultural, ritual Symbol', (original Afrikaans), Koers 67(3), 1-26.

2003, 'The Christmas Eve dialogue of Fredrich Schleiermacher in Afrikaans: Background, translation and hermeneutics', HTS Teologiese Studies/Theological Studies 59(2), 545-568.

2003, (co-author, Geyser, P.A.), '"Keeping theology within the parameters of Scripture' - consistency and development in the theology of Piet Geyser', (original printed in Afrikaans), HTS Teologiese Studies/Theological Studies 60 (1\&2), 7-28.

2003, 'Perspective on Scripture in light of postmodernity', (original printed in Afrikaans), HTS Teologiese Studies/Theological Studies 60(1\&2), 503-532.

2003, 'Jesus as Joshua, Moses en Dawidiese Messias in Matteus', Scriptura 84(3), 453-467.

2003, 'Does historical Jesus research have a future?', Verbum et Ecclesia 24(2), 533-556. 2003, 'Theorizing about myth', Acta Patristica et Byzantina 14, 245-265.

2003, 'Die heroïese mite van die kind-god Jesus in die Kindheidsevangelie van Tomas', Acta Patristica et Byzantina 14, 266-302.

2004, 'Postmodern epistemology and postcolonial hermeneutics' (original printed in Afrikaans), HTS Teologiese Studies/Theological Studies 60(3), 1105-1125.

2004, 'Jesus' affection toward children and Matthew's tale of two kings', Acta Theologicae 24(2), 127-146.

2004, "Jesus and the Son of Man: A shift from the "little tradition" to the "great Tradition"', Ephemerides Lovaniensis Theologicae 80, 423-438, [a reworked version of the Afrikaans published in 2002,'“The expression "son of man" in the Jesus tradition: A development from agrarian culture to a scribal context', HTS Teologiese Studies/ Theological Studies 58 (4), 1625-1653].

2004, 'The earliest Jesus group in Jerusalem', Verbum et Ecclesia 25(2), 711-738.

2005 , 'Faith as response to reconciliation - a Pauline perspective', (original printed in Afrikaans), Verbum et Ecclesia 26(1), 222-243.

2005, 'Die Kindheidsevangelie van Tomas - historiese allegorie of mite in die vorm van 'n biografiese diskursiewe evangelie?', HTS Teologiese Studies/Theological Studies 61(1\&2), 461-489.

2005, 'The Greek manuscript of the Infancy Gospel of Thomas in Codex Sinaiticus (Gr 453) translated into Afrikaans', (original printed in Afrikaans), HTS Teologiese Studies/ Theological Studies 61(1\&2), 491-516.

2005, 'The Infancy Gospel of Thomas: Allegory or myth? - Gnostic or Ebionite?', Verbum et Ecclesia 26(3), 826-850.

2005, 'Cultural criticism as an imperative for Christians', HTS Teologiese Studies/ Theological Studies 61(3), 683-708.

2005, (co-author, Rukundwa, L.S.), 'Revisiting justice in the first four beautitudes in Matthew (5:3-6) and the story of the Canaanite woman (Mt 15:21-28): A postcolonial reading', HTS Teologiese Studies/Theological Studies 61(3), 927-951.

2005, (co-author, Boshoff, H. [Cules] J. Boshoff), 'Grieks-Romeinse apokaliptiek en die Christelike kerugma, HTS Teologiese Studies/Theological Studies 61(4), 1131-1148.

2005, (co-author, In-Cheol, S.), 'Matthew's and Paul's inclusive tendencies: A comparison', HTS Teologiese Studies/Theological Studies 61(4), 1353-1372.

2005, (co-author, Ingram, R.), 'Van Plato tot Augustinus: Die vroeë Wirkungsgeschichte vandie Logos-motief in Johannes', Ekklesiastikos Pharos (New Series 16) 87, 235-258. 2005, (co-author, Howes, L.), "n Pre-kanonieke bron van die leë graf tradisie',

Ekklesiastikos Pharos (New Series 16) 87, 301-324.

2006, 'Ebionite tendencies in the Jesus Tradition: The Infancy Gospel of Thomas interpreted from the perspective of ethnic identity', paper presented at the SBL, Philadelphia (USA), November 2005, [published in Neotestamenica 40(2), 353-382].

2006, (co-author, Groenewald, J.), 'The role alternate states of consciousness played in the baptism and Eucharist of the earliest Jesus followers', HTS Teologiese Studies/ Theological Studies 62(1), 41-67.

2006, (co-author, Cromhout, M.), 'A socio-cultural model of Judean ethnicity', HTS Teologiese Studies/Theological Studies 62(1), 69-101.

2006, "Hoe om in te kom en hoe om binne te bly - die "groot sendingopdrag" aan die kerk vandag volgens Matteus 28:16-122', HTS Teologiese Studies/Theological Studies 62(1), 103-122.

2006, 'Genre en plot georiënteerde naratief-kritiese eksegese van Evangeliemateriaal: Inleiding tot narratiewe kritiek', HTS Teologiese Studies/Theological Studies 62(2), 657-677.
2006, (co-author, Dannhauser, E.), 'Jesus - prophetic emissary of God', HTS Teologiese Studies/Theological Studies 62(2), 425-444.

2006, 'Vertellersperspektiefanalise van Nuwe-Testamentiese tekste', HTS Teologiese Studies/Theological Studies 62(3), 1111-1143.

2006, 'Die narratiewe blikhoek in die mikrovertelling oor die genesing van die koninklike se seun in Johannes 4:43-54', HTS Teologiese Studies/Theological Studies 62(4), 1439-1451.

2006, (mede-outeur, Jones, R.), "n Kerugmatiese perspektief op bedieninge in die Nuwe Testament', HTS Teologiese Studies/Theological Studies 62(4), 1489-1511.

2007, 'Inleiding tot die sosiaal-wetenskaplike kritiese eksegese van NuweTestamentiese tekste: Die metodologiese aanloop in die navorsingsgeskiedenis', HTS Teologiese Studies/Theological Studies 63(1), 49-79.

2007, (mede-outeur, Dreyer, A.E.), 'Bybelse modelle van die huwelik: 'n Kritiese perspektief', HTS Teologiese Studies/Theological Studies 63(2), 625-651.

2007, (mede-outeur, Dreyer, A.E.), "n Krities-hermeneutiese perspektief op die huwelik in ' $n$ postmoderne era', HTS Teologiese Studies/Theological Studies 63(2), 653-681.

2007, 'Die sosiaal-wetenskaplike kritiese eksegese van Nuwe-Testamentiese Tekste: 'n Kritiese oorsig van die eerste resulate', HTS Teologiese Studies/Theological Studies 63(2), 515-542.

2007, (co-author, Rukundwa, L.S.), 'The formation of postcolonial theory', HTS Teologiese Studies/Theological Studies 63(3), 1171-1194.

2007, 'Sosiaal-wetenskaplike kritiese eksegese van Nuwe-Testamentiese tekste - ' voortgaande debat sonder einde', HTS Teologiese Studies/Theological Studies 63(3), 1119-1147.

2007, (co-author, Pelser, G.M.M.), 'The historical-hermeneutical prelude to the legacy of Karl Barth', HTS Teologiese Studies/Theological Studies 63(4), 1347-1375.

2007, (co-author, Pelser, G.M.M.), 'Historical consciousness and existential awareness in Karl Barth's hermeneutics', HTS Teologiese Studies/Theological Studies 63(4), 13771411.

2007, 'Jesus' mission to all of Israel emplotted in Matthew's story', Neotestamentica 41(2), 416-436.

2008, (co-author, Human, D.J.), 'HTS Theological Studies and Verbum et Ecclesia - the journals of the Faculty of of Theology at the University of Pretoria: Historical overview and strategic planning', HTS Teologiese Studies/Theological Studies 64(1), 9-24.

2008, “Anthropological rabbits" and "positivistic ducks": An experiential reflection on Pieter Craffert's "shamanic Jesus"', HTS Teologiese Studies/Theological Studies 64(2), 767-798.

2008, "What is "theology" in "public theology" and what is "public" about "public theology?"', HTS Teologiese Studies/Theological Studies 64(3), 1213-1234.

2008, "Paulus se versie van "draai die ander wang" - gedagtes oor geweld en toleransie', HTS Teologiese Studies/Theological Studies 64(4), 1667-1697.

2009, 'Postsecular spirituality, engaged hermeneutics, and Charles Taylor's notion of hypergoods', HTS Teologiese Studies/Theological Studies Teologiese Studies/ Theological Studies 65(1), Art. \#166, 8 pages. DOI: 10.4102/hts.v65i1.166.

2009, 'Intertekstualiteit - ensiklopedie en argeologie: Matteus se voorstelling van Jesus as redder', HTS Teologiese Studies/Theological Studies 65(1), Art. \#156, 10 pages. DOI: $10.4102 / \mathrm{hts} . v 65 i 1.156$.

2009, 'God, the Christ and the Spirit in William P. Young's bestseller The shack seen from a Pauline and Johannine perspective', HTS Teologiese Studies/Theological Studies 65(1), Art. \#305, 9 pages. DOI: 10.4102/v65i1.305.

2009, “'Foxes' holes and birds' nests" (Mt 8:20): A postcolonial reading for South Africans from the perspective of Matthew's anti-societal language', HTS Teologiese Studies/Theological Studies 65(1), Art. \#318, 10 pages. DOI: 10.4102/hts.v65i1.318.

2009, 'Theological trends in our postsecular age', Verbum et Ecclesia 30(3), 1-8. DOI: 10.4102/ve.v30i3.178

2010, (co-author, Dreyer, Y.), 'Matthew studies today - a willingness to suspect and a willingness to listen', HTS Teologiese Studies/Theological Studies 66(1), Art. \#820, 10 pages. DOl: 10.4102/hts.v66i1.820.

2010, 'Understanding Jesus healings: Shrinking history and Donald Capps's different thinking Cap', HTS Teologiese Studies/ Theological Studies 66(1), Art. \#821, 5 pages. DOI: $10.4102 /$ hts.v66i1.821.

2011, 'Rudolf Bultmann: Sy mees invloedryke bydrae in die 20ste eeu: "Urchristentum", "Jesus", “Johannes"-kommentaar?"', HTS Teologiese Studies/Theological Studies 67(3) (forthcoming).

2011, 'Regeneration and resurrection in Matthew - Peasants in campo hearing time signals from scribes HTS Teologiese Studies/Theological Studies (3), (forthcoming).

2011, 'Texts, co-texts, and con-texts of the empty tomb in the Jesus tradition", in Festschrift Tjaart van der Walt, In die Skriflig 45(1), 2011 (forthcoming) (original in Afrikaans).

2012, 'Die pelgrim se reis teen mag in drie "Sondergut"-gelykenisse in Lukas 15 en 16 , Voordrag gelewer by die NavNUT Konferensie oor 'Mag in die Nuwe Testament', 16-19 Januarie 2011, Universiteit van Stellenbosch, (forthcoming in HTS Teologiese Studies/Theological Studies 68).

\section{Books}

1989, Handelinge 7:48 - 'Die Allerhoogste woon nie in mensgemaakte konstruksies nie': Die relevansie van die Nuwe-Testamentiese Wetenskap na aanleiding van die metafoor "tempel", Van Schaik, Pretoria (ISBN 0869797638). 
1994, 'God-with-us': The dominant perspective in Matthew's story and other essays, Gutenberg Publishers, Pretoria (ISBN 0958320837).

1994, Kultuurhistoriese agtergrond van die Nuwe Testament: Die eerste-eeuse Mediterreense sosiale wêreld, Kital Uitgewers, Pretoria (ISBN 1874900183).

1996, (co-author, Pelser, G.M.M.), Corpus Paulinum: Inleiding en teologie, Kital Publishers, Pretoria (ISBN 1874909175).

1998, (co-contributor), The Acts of Jesus: What did Jesus really do? The search for the authentic deeds of Jesus, edited by Funk, R.W. and the Jesus Seminar, A Polebridge Book, HarperSanFrancisco, San Francisco, CA (ISBN 0060629789).

2001, Fatherless in Galilee: Jesus as child of God, Trinity Press International, Harrisburg, PA (ISBN 1563383454).

\section{Chapters in books}

1983, 'Vertellersperspektiefanalise', in A.G. van Aarde (red.), Interpretasiemodelle in Evangelienavorsing, Universiteit van Pretoria, Pretoria (UP 225.6).

1984, 'Die weg van die teks na die preek: Die verkondiging van die Nuwe Testament as kommunikasie-gebeurtenis', in A.J. Smuts (red), Die woord aan die werk, pp. 77-92, NG Kerkboekhandel, Pretoria. [Republished in HTS Teologiese Studies/Theological Studies 40(2), 145-147].

1985 , 'Romeine 6:1-14 as ' $n$ voorbeeld van ' $n$ argumentatiewe teks met die oog op eksegese en prediking', in A.J. Smuts (red.), Die woord aan die werk, pp. 127-136, NG Kerkboekhandel, Pretoria.

1986, 'Plot as mediated through point of view: Mt 22:1-14 - a case study', in J.H. Petzer \& P.J. Hartin (eds.), A South African perspective on the New Testament: Essays by South African scholars presented to Bruce Manning Metzger during his visit to South Africa in 1985, pp. 62-75, E.J. Brill, Leiden.

1988, 'Historical criticism and holism: Heading towards a new paradigm', in J. Mouton A.G. van Aarde \& W.S. Vorster (eds.), Paradigms and progress in theology, pp. 49-64, HSRC Studies in Research Methodology No.5, HSRC, Pretoria.

1988 , 'The struggle against heresy in the Thessalonian correspondence and the origin of the apostolic tradition', in R.F. Collins (ed.), The Thessalonian Correspondence, pp. 418-425, Peeters Publishers, Leuven.

1991, 'A silver coin in the mouth of a fish (Mt 17:24-27): A miracle of nature, ecology, economy, and the politics of holiness' (original printed in Afrikaans, in Humankind and environment, pp. 216-237, ed. C. Vos \& J. Müller, Orion Publishers, Halfway House), translated and republished in Van Aarde, A.G., 1994, 'God-with-us': The dominant perspective in Matthew's stories and other essays, pp. 204-228, Gutenberg Publishers, Pretoria.

1991, 'Narrative criticism applied to John 4:43-54', in P.J. Hartin \& J.H. Petzer (eds.) Text and interpretation: New approaches in the criticism of the New Testament, pp. 101-128, New Testament Tools and Studies 15, E.J. Brill, Leiden.

1992, 'The "Evangelium Infantium", the abandonment of children, and the infancy narrative in Matthew 1 and 2 from a social-scientific perspective'"' in Society of Biblical Literature 1992 Seminar Papers, pp. 435-453, ed. E.H. Lovering, Scholars Press, Atlanta, GA.

1994, 'Organismic holism in the light of the modernity-postmodernity debate', in J. Mouton \& B.C. Lategan (eds.), The relevance of theology for the 1990s, pp. 603-618, HSRC, Pretoria.
1994, 'A study of the New Testament beatitude and the beatitude series in Matthew 5:3-10: A new approach to "Gattungsforschung"', in A.G. van Aarde, 'God-with us'. The dominant perspective in Matthew's stories and other essays, pp. 151-179, us': The dominant perspective
Gutenberg Publishers, Pretoria.

1994, 'The miraculous multiplications of loaves (Mt 14:13-21 and par): Historical criticism in perspective', in A.G. van Aarde, 'God-with-us': The dominant perspective in Matthew's stories and other essays, pp. 180-203, Gutenberg Publishers, Pretoria.

1994, 'A historical-critical classification of Jesus' parables and the metaphoric narration of the wedding feast in Matthew 22:1-14', in A.G. van Aarde, 'God-withus': The dominant perspective in Matthew's stories and other essays, pp. 229-247, Gutenberg Publishers, Pretoria.

1994, “He has risen from the dead" (Mt 28:7): A textual evidence on the separation of Judaism and Christianity', in A.G. van Aarde, 'God-with-us': The dominant perspective in Matthew's stories and other essays, pp. 248-260, Gutenberg Publishers, Pretoria.

1999, 'Wat is die waarheid? ' $n$ Teologiese antwoord van 'n Bybelwetenskaplike', in D.J.C. Van Wyk sr. (red.), 20ste eeu Hervormde teologie, pp. 11-27, Sentik Uitgewers, Pretoria.

2002, 'Jesus als vaterloses Kind: Eine kulturübergreifende und sozialpsychologische Perspektive'"' in W. Stegemann, G. Theissen \& B.J. Malina (Hrsg.), Jesus in neuen Kontexten, pp. 98-111, Kohlhammer, Stuttgart.

2002, 'Jesus as fatherless child', in Malina, B.J. et al. (ed.), The social setting of Jesus and the Gospels, pp. 65-84, Fortress Press, Minneapolis, MN.

2004, 'Social identity, status envy, and Jesus as fatherless cild', in J.H. Ellens \& W.G. Rollins (eds.), Psychology and the Bible: A new way to read the Scriptures, Volume 4: From Christ to Jesus, pp. 223-246, Praeger Perspectives: Psychology, Religion, and Spirituality, Praeger Press, Westport, CT.

2005, 'IHSOUS - The Davidic Messiah as political saviour in Matthew's History', in J.G. Van der Watt (ed.), Salvation in the New Testament: Perspectives on soteriology, pp. 7-31, Supplements to Novum Testamentum 121, E.J. Brill, Leiden.

2005, 'Resolving communication disturbances in Luke 12:35-48 through Narratology', in U. Berges \& P. Chatelion Counet (eds.), One text, a thousand methods: Studies in memory of Sjef van Tilborg, pp. 161-178, E.J. Brill, Leiden.

2008, 'Matthew's intertexts and the presentation of Jesus as healer-messiah', in T.R Hatina (ed.), Biblical interpretation in early Christian gospels: The Gospel of Matthew, vol. 2, pp. 163-182, T\&T Clark, New York.

2009, 'Narrative criticism', in A.B. du Toit (ed.), Focusing on the message: New Testament hermeneutics, exegesis and methods, pp. 381-418, Protea, Pretoria.

2009, (co-author, Joubert, S.J.), 'Social-scientific criticism', in A.B. du Toit (ed.), Focusing on the message: New Testament hermeneutics, exegesis and methods, pp. 419-456, Protea, Pretoria.

2010, “'On earth as it is in heaven": Matthew's eschatology as the kingdom of heaven that has come', in J. Frey \& J.G. van der Watt (eds.), Eschatology in the New Testament, WUNT, Siebeck Mohr, Tübingen.

2011, 'Paul's version of "turn the other cheek" - rethinking violence and tolerance', in J.-W. Van Henten \& P.G.R. de Villiers (eds.), E.J. Brill, Leiden. 